\title{
Practices of Critical Managerial Skills: A Comparison among Japanese, Chinese and Taiwanese Managers*
}

\author{
Mitsuru WAKABAYASHI (Graduate School of International Development, Nagoya University, Japan) \\ Ziguang CHEN ${ }^{* *}$ (Graduate School of International Development, Nagoya University, Japan), and \\ Kuo Long HUANG (College of Management, National Taiwan University, Taiwan)
}

This study was designed to explore managerial skills required for managers working for the corporations in Japan, China and Taiwan. For the purpose of comparing differences in the pattern of managerial skill practices, Chinese managers in state-owned $(n=276)$ and joint venture $(n=186)$ corporations, Japanese managers $(n=377)$ in Japanese corporations and Taiwanese managers $(n=139)$ in Taiwanese corporations were asked to respond the Managerial Skill Questionnaires (total $N=978$ ). The MSQ using the 22 skill items asked managers to report how frequently they practice each skill based on a 5-point scale, and choose the five most important skills needed for them to improve their managerial job performance in their organizations.

Results of the data analyses indicated that the four major skill factors, namely Organizational Development (OD), Organizational Goal Attainment (OGA), Proper Use of Personnel (PUP) and Technical Skills (TS) are salient as common skill dimensions among sample managers. Particularly, both Chinese and Taiwanese managers were found practicing PUP and teamwork skills more frequently, while Japanese managers practicing OD skills relatively more than others. The analysis of critical skills for improving managerial performance indicated that Japanese managers identify strategic, problem identification and decision making skills to be most critical, while Chinese and Taiwanese managers do people-oriented and teamwork skills most critical for improving their job performance. But, Taiwanese were found different from Chinese managers in emphasizing the teamwork skill and technical expertise more than their Chinese colleagues who tend to choose fair treatment and quality control skills to be more critical. These findings were interpreted based on differences in culture and the nature of market pressures in which managers working in each country.

\section{Introduction}

Relative to abundant observations on the Asian economy and business, little is known about the business organizations and managers in Asian countries (Lim, 1996). Although many studies have done in the area of cultural values and tradi-

* A part of this paper was presented at the $12^{\text {th }}$ Annual Meeting of the Association of Japanese Business Studies (AJBS) held in Salt Lake City, Utah, USA, on June 4-6, 1999. This study is supported by the research grant by the Chiang Ching Kuo Foundation for International Scholarly Exchange provided for the cross-cultural investigation of managerial skills proposed by Mitsuru Wakabayashi (project leader), Ziguang Chen (Nagoya University) and Kuo Long Huang (National Taiwan University) for the 1998-1999 period.

** Ziguang Chen is a postdoctoral research fellow of Japan Society for the Promotion of Science (JSPS). tions unique to the Asian businesses (Redding, 1990; Hofstede, 1980; Hofstede and Bond, 1988), available information is very limited regarding what Asian managers are doing on their jobs, whether they are equally skillful as Western colleagues, and how they are contributing to the business success in each Asian country.

On the other hand, evidence is abundant that suggests managers working in the different cultural environment believe in different values (Hofstede, 1980: Hofstede and Bond, 1988; Laurent, 1983; England, 1978; Adler, 1991). Also, many studies reported that not only value systems but also decision making styles (Boulgarides \& Oh, 1985; Kagono, Nonaka, Sakakibara and Okumura, 1975) and styles of negotiation (Fisher, 1980; Adler, 1991) may vary cross-culturally. All these evidence may direct us to hypothesize that 
managerial skills and knowledge needed for the effective managerial performance may vary significantly, according to the difference in national and cultural background of individual managers.

Contrary to the above, there exist many findings to suggest that skills and knowledge required for managers can be identical across organizational and cultural differences. For example, studies conducted by Bray and his associates at AT \& $\mathrm{T}$ based on the assessment center approach (Bray, Campbell and Grant, 1974) and a study done by Mintzberg on managerial roles (Mintzberg, 1973) all suggest that skills of organizing, planning, negotiating, decision making, human relations, leadership, and so forth are required to those who to be effective manager. But, these studies were conducted dealing with managers working for large industrial organizations in the Western societies. The question here is whether the managerial skills required for the competent Western managers would be equally needed for managers working under the different organizational and cultural settings, namely for managers in Asian countries.

Given the importance of developing managerial skills and knowledge for Asian managers, it is quite interesting to study how Asian managers are actually practicing their skills of management for running and developing their business organizations faced with the increasingly competitive international market. Particularly, studies on managers in Chinese corporations must be very exciting in view of the fact that strong pressures toward the structural reform and management development have been placed on the Chinese state-owned corporations since 1990s. Chinese managers both in state-owned and joint venture corporations have long struggled to develop their managerial capabilities to cope with the prevailing market economy and global competition (Chen and Wakabayashi, 1997b; Wang, 1990), yet managerial reform must go a long way in China.

Likewise, the Taiwanese corporation characterized with its traditional organizational culture of familism and guanxi network (Hwang, 1995) is now transforming itself toward the more professional business organization. It is reported this trend is conspicuous among the fast growing Taiwanese SMEs where young highly educated entrepreneurs are succeeding their old laoban entrepreneurs (Wakabayashi and Chen, 1999) with their professional skills and global business orientations. Moreover, business activities of foreign multinational corporations (MNC) have been very active in Taiwan. Therefore, Taiwanese managers working for these MNCs may have acquired a set of skills and knowledge which are considered equivalent to those of their foreign expatriate managers. If this diffusion process of Western-born managerial skills into the Taiwanese management population has occurred very extensive for the past decades, the managerial skill mix among Taiwanese managers may look quit different from Chinese and Japanese managers.

In Japan, the accelerated expansion of foreign direct investment by Japanese MNCs in recent years has forced managers in charge of international HRM to consider ways to develop the effective management organization in the affiliated foreign firms (Ishida, 1995). Most of the Japanese MNCs now have the international HRM sections to deal with growing international HRM issues. Their main functions, however, tend to remain within rather routine personnel tasks: selecting, training and dispatching Japanese managers for foreign assignments (Sawaki, 1993). But, needs for the strategic IHRM are growing rapidly beyond these immediate personnel concerns. Particularly, development of managerial skills and the management organizations in the crosscultural context increasingly become to challenge major Japanese corporations. Therefore, needs for understanding the status of managerial skills of Japanese managers within the international business community is drawing more attention than ever in the context of increasingly globalizating business activities of Japanese firms.

\section{Purpose of the Study}

In view of these circumstances, the present study 
was designed to explore the differential characteristics in managerial skill practices among Japanese, Chinese and Taiwanese managers in a comparative perspective. To explore managerial skill practices in Japan, China and Taiwan in a comparative perspective, a series of surveys were attempted using the Managerial Skill Questionnaire (MSQ), by inviting the middle to uppermiddle managers as respondents in each country (Wakabayashi and Chen, 1999). Through this comparison, it is expected that the nature of managerial skill practices in each country can be explained in terms of differences in national culture, business and economic environment, and the development stage of the management organization.

The following two hypotheses were developed for the purpose of explaining the differences in the pattern of managerial skill practices among Japanese, Chinese and Taiwanese managers.

Hypothesis 1: The pattern of managerial skill practices is different among Japanese, Chinese and Taiwanese managers. Namely, it is expected that both Chinese and Taiwanese managers practice people-oriented skills more frequently, while Japanese managers do businessoriented skills relatively more.

More precisely, Chinese and Taiwanese managers who are under the influence of collectivism and Confucian culture (Hofstede, 1980; Hofstede and Bond, 1988) are prone to use people-oriented skills (namely, human relations, fair treatment, and teamwork skills, etc.) more frequently, while their Japanese counterparts who are considered being confronted with the keener competitive pressures from the international market and global technological innovation, tend to use problem solving and strategic thinking skills (namely, problem identification, strategic thinking, decision making skills and so forth) more frequently. Particularly, in Chinese SOCs where separation of management functions from state ownership of the firm is yet to be fully realized and professionalization of managers is slow to be established, managers in general are likely to be confronted relatively less with high performance targets and competitive business deals, but more with the in-house social and economic issues like harmony, solidarity and distributive justice problems within the corporation (Redding and Wong,1986; Wang, 1990), relative to those in Chinese JVCs, Japanese and Taiwanese corporations.

In summary, Hypothesis 1 predicts that the people-oriented skills are more frequently practiced by managers in Chinese SOCs followed by those in Chinese JVCs, Taiwanese and Japanese corporations. On the other hand, skills of business problem solving, like those of strategic thinking and decision making, are more frequently practiced by Japanese managers, followed by Taiwanese, and Chinese SOC and JVC managers in this order.

Hypothesis 2: Managerial skills that Japanese, Chinese and Taiwanese managers choose as needed for improving their performance on the job are different. Following Hypothesis 1, Chinese managers both in SOCs and JVCs will choose a set of people-oriented skills as needed for increasing their performance on the job, while Taiwanese managers will choose partnership and goal attainment skills. On the other hand, again following Hypothesis 1, Japanese managers are expected to choose skills for problem identification and strategic decision making as needed for improving their managerial performance.

Skills needed for improving managerial performance is called here critical skills. For Chinese managers, people-oriented skills like fair treatment and proper use of personnel, are expected to be chosen as critical skills based on the same reasons as explained in Hypothesis 1. This will hold true both in SOCs and JVCs, because in both SOCs and JVCs managers must work together with Chinese subordinates for improving job performance. On the other hand, for Taiwanese managers the critical skill area is expected to be in 
the teamwork and achievement of goals based on the cooperation among team members. One of the characteristics of the Taiwanese business style rests on the formation of partnership relationship among entrepreneurs (Hwang, 1995). Therefore, effective Taiwanese managers are expected to have skills of teamwork and group goal-attainment based on their personal expertise.

On the other hand, as Hypothesis 1 suggests, the critical skill area for Japanese managers will include skills of strategic thinking, problem identification, decision making, innovation and so forth, namely a set of skills for changing and developing the business and organization. These change skills are expected to be critical for Japanese managers who must confront the keen global competition and the rapid technological change.

\section{Research Method}

\section{Data Collection}

The present study was designed to answer the research questions and hypotheses stated above based on the comparison among Japanese, Chinese and Taiwanese managers with respect to their skill practices in their organizations. A series of questionnaire surveys on managerial skills were conducted between 1996 and 1998. The first attempt of the Chinese version questionnaire surveys was made in Chinese corporations in 1996 involving top, middle and lower-middle managers in the manufacturing industry covering both state-owned corporations (16 SOCs, $\mathrm{n}=276$ ) and Sino-foreign joint ventures (five Sino-Japan, five Sino-Hong Kong and Macao, and five Sino-US and UK JV corporations, $n=186$ ). State-owned and joint venture corporations in China were selected from four cities in Zhejinag Province (Hangzhou, Ningbo, Shaoxing and Fuyang ), with the cooperation given by the provincial offices. Basically the same method was repeated for the Japanese study in 1997, involving 377 manages from nine manufacturing corporations from the central Japan area as respondents to Japanese version questionnaires. The Taiwanese study conducted in 1998 asked 139 managers, mostly from four major Taiwanese Corporations and the rest from the executive MBA classes at National Taiwan University, to respond the Taiwanese version questionnaires. Japanese and Chinese studies involved manages only from the manufacturing industry as respondents, while for the Taiwanese study those from the service, finance, trade and communication industries were included in the sample. Although all managers sampled engaged in managerial jobs (in other words no engineers and technical specialists were included), a slight difference in the composition of sample managers between the Japanese and Chinese studies, and the Taiwanese study may require a careful attention when interpreting the results.

\section{Instruments}

The Managerial Skill Questionnaire (MSQ) used for the study included the 22 skill items. They are considered relevant for managers to discharge their responsibilities based on the review of the assessment center literature (Bray, Campbell and Grant, 1974; Finckle, 1978; Wakabayashi, 1980), the managerial role studies (Mintzberg, 1973; Szilagyi and Wallace, 1987), and managerial leadership making studies (Graen and Cashman, 1975, Wakabayashi and Graen, 1984, 1988; Chen and Wakabayashi, 1997a). The Japanese, Chinese and Taiwanese version questionnaires were developed through translations from the standard English version questionnaire and tested in each country by a pilot survey for modifications in wording and sentence structure to meet local situations. The MSQ contained the following two sets of questions.

(1) Managerial Skills in Practice: The 22 managerial skills, for example a strategic thinking skill, a decision making skill, a communication skill and so forth, were presented with a short sentence paraphrasing the content of each skill. For example, Strategic Thinking Skill was given an explanation that states: "(This skill) considers market situations, competitors, future goals and longterm company prosperity, when making decisions." The managers were asked to respond how frequently they use these skills in their day-to-day managerial work by using a 5 -point scale ranging 
from "using everyday" $(=5)$ through "sometimes" (=3) to "not at all" (=1). For other MSQ items, please see Appendix 1.

(2) Five Most Important Skills: Out of the above 22 skill items, the subject managers were asked to select, in order of importance, the "five most important skills" which they think needed for improving the present level job performance.

The questionnaire included other question items related to managerial skills, but for the present study results from the above two questions only are reported.

\section{Results}

\section{Factor Analysis and Construction of MS Scales}

A factor analysis (principal factors with Varimax rotation) was conducted based on all managers sampled for this study for the purpose of constructing MS scales by combining intercorrelated skill items into a single composite scale. The factor analysis produced four factors: 1) Skills of Organizational Goal Attainment (OGA), 2) Proper Use of Personnel (PUP), 3) Organizational Development (OD), and 4) Technical Skills (TS). Skill items constituting each factor and summary results of the factor analysis are presented in Appendix 2.

The first OGA factor implies skills to enhance the group-based goal attainment through presenting missions, promoting teamwork, motivating subordinates and so forth. The second, proper use of personnel (PUP) indicates skills of being sensitive to: group members' needs, fair treatments, customer needs and the profit. In other words, this skill implies using people properly to let them serve consciously customers and profits of the company. Thirdly, the skills of organizational development (OD) indicates managers capabilities of working for the long-term and strategic issues for running the organization by: thinking strategically, identifying problems and making decisions. Finally, technical skills (TS) mean the technical expertise in handling managerial tasks. Items constituting each factor were put together and an composite score was computed for each factor as an average of item scores. As shown in
Appendix 2, all scales created based on the above procedures were found to have satisfactorily high reliability coefficients computed in terms of Cronbachs alphas.

A series of statistical analyses were attempted for comparing the levels and patterns of managerial skill practices among Japanese, Chinese (both in SOCs and JVCs) and Taiwanese managers involving the above four skill dimensions. Also, the analysis on critical managerial skills was conducted by examining differences among four groups of managers in their choice frequencies of the Five Most Important Skills.

\section{Cross-cultural Differences in Managerial Skill} Practices: A Comparison among Japanese, Chinese and Taiwanese Managers

For the purpose of exploring Hypothesis 1 regarding to what extent managerial skill practices are different among Japanese, Chinese and Taiwanese managers, the following four groups of managers were compared with respect to their managerial skill practices, namely, Japanese managers, Chinese managers in SOCs and JVCs, and Taiwanese managers. Figure 1 displays the result of a comparative analysis on the frequency of managerial skill practices reported by the four groups of managers.

Figure 1 illustrates that generally speaking the managerial skills are reported in practice most frequent by Taiwanese managers, followed by those in Chinese JVCs and SOCs in all four skill dimensions. Particularly, people-oriented skills (Proper Use of Personnel; PUP) were found most frequently practiced, not by Chinese, but by Taiwanese managers. This result proves the opposite to what is predicted by Hypothesis 1 that states people-oriented skills are to be most frequently practiced by Chinese managers in SOCs, followed by those in JVCs and Taiwanese corporations. However, Hypothesis 1 holds true in Figure 1 by correctly demonstrating that Japanese managers are practicing PUP skills least frequently in all four groups. The difference between Taiwanese and Japanese managers in PUP skill practices is just striking. The same pattern of differences 


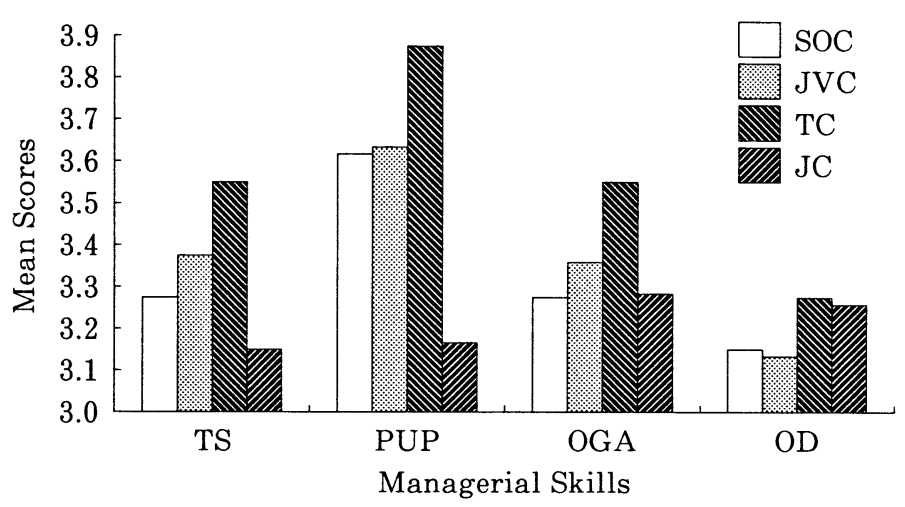

Figure 1 Opportunities to Use Managerial Skills for Managers in four Different Mamagement Organizations

among four groups is found in TS (Technical Skills) and OGA (Organizational Goal Attainment) skill practices. These differences are all statistically significant at the $\mathrm{p}<.05$ level. Why Taiwanese managers report most frequent practices of these skills needs careful examinations.

In Figure 1 if we pay attention to the pattern, not the absolute frequency, of skill practices, a quite different picture can be found between Japanese managers and others. Namely, for Japanese managers the most frequently practiced skills are OD (Organizational Development) and OGA, in other words skills for strategic thinking, problem solving and improving business performance, while people-oriented PUP and Technical Skills are relatively less frequently practiced. On the contrary, for Taiwanese and Chinese managers the opposite is true. Based on this finding, it is concluded that Hypothesis 1 is supported in principle given that Chinese and Taiwanese managers under the strong influence of collectivism and Confucian cultural traditions are more peopleoriented in managerial skill practices, while Japanese colleagues tend to be more strategic, and problem-and decision-oriented in their skill practices.

The first line of explanation to the above finding is made by following the assumption of cultural differences as Hypothesis 1 suggests. The second way to explain the result is to focus on differences in the nature of market pressures with which the sample manages are driven to confront on their jobs. Namely, Japanese managers are expected to be challenged more strongly by the domestic as well as international market forces in solving their managerial problems, while Taiwanese and Chinese managers are relatively less severely confronted with these competitive pressures. This may be the reason why Japanese managers become driven to use OD skills (problem identifying, decision making, strategic thinking and innovation skills) more of ten than Chinese and Taiwanese colleagues. The third explanation can be given by the stage theory of managerial skill development. More precisely, Chinese corporations are considered remaining at the lower stage in its organizational and management development where technical and people-related skills are dominantly practiced, while Japanese corporations are approaching the higher stage of management development where a set of organizational development (OD) and innovation skills are rigorously exercised. Taiwanese corporations may be located between the two. If we follow this line of reasoning, differences in the pattern of managerial skill practices must be attributable to the different nature of organizational contexts in which managerial skills are nurtured and practiced.

In summary, more empirical evidence is required to evaluate the validity of the above three propositions which may be summarized 
respectively as: (1) cultural, (2) market-driven, and (3) development stage theories of the managerial skill practices. However, it will be wrong to emphasize only one determinant to the exclusion of others; All three, or a certain combination among them, may be working simultaneously in influencing the frequency of practicing a particular set of managerial skills.

\section{Critical Managerial Skills}

To test Hypothesis 2, an analysis was made for identifying a set of critical managerial skills needed for improving managerial performance. The second part of the MSQ survey asked managers to choose in order the "five most important skills" that they consider required for improving the present level of job performance, out of the 22 skill items presented in the questionnaire. Table 1 presents the first 10 most frequently cited skills (disregarding the order of importance) out of the pool of managers' choices of five critical skills for SOC, JVC, Japanese and Taiwanese manager groups. The result clearly illustrates that the first ten skills most frequently chosen by managers in Chinese SOCs and JVCs are quite similar. A rank order correlation coefficient computed using the Spearman's formula between the two groups involving the first ten skills listed in Table 1 was found very high, i.e., $\mathrm{r}_{\mathrm{s}}=.83, \mathrm{p}<.01$ (see Table 2). This result gives support to the findings of the past study conducted by Chen and Wakabayashi (1997b) based on the manager group from Chinese

Table 1 The first 10 most frequently cited managerial skills for managers in Chinese SOCs and JVCs, Japanese corporations, and Taiwanese corporations respectively for improving their managerial performance on the present job, chosen in order of importance from Rank 1st to Rank 5 th

\begin{tabular}{|c|c|c|c|c|c|c|c|c|c|c|c|}
\hline \multirow{3}{*}{ No } & \multirow{2}{*}{\multicolumn{2}{|c|}{$\begin{array}{c}\mathrm{A}: \mathrm{SOC} \\
(\mathrm{n}=276)\end{array}$}} & \multirow{2}{*}{\multicolumn{2}{|c|}{$\begin{array}{c}\text { B: JVC } \\
(n=186)\end{array}$}} & \multirow{2}{*}{\multicolumn{2}{|c|}{$\begin{array}{c}\mathrm{C}: \mathrm{JC} \\
(\mathrm{n}=377)\end{array}$}} & \multirow{2}{*}{\multicolumn{2}{|c|}{$\begin{array}{c}\mathrm{D}: \mathrm{TC} \\
(\mathrm{n}=139)\end{array}$}} & \multicolumn{3}{|c|}{$\mathrm{Z}$ value } \\
\hline & & & & & & & & & $A-B$ & $A-C$ & $A-D$ \\
\hline & Rank & Freq. & Rank & Freq. & Rank & Freq. & Rank & Freq. & $B-C$ & $B-D$ & $\mathrm{C}-\mathrm{D}$ \\
\hline \multirow{2}{*}{ - 1 Strategic thinking } & 1 & 150 & 3 & 80 & 1 & 175 & 5 & 42 & $2.38^{b}$ & $1.99^{\mathrm{a}}$ & $4.65^{\circ}$ \\
\hline & & $(54.3 \%)$ & & $(43.0 \%)$ & & $(46.4 \%)$ & & $(30.2)$ & .76 & $2.36^{\circ}$ & $3.31^{\mathrm{c}}$ \\
\hline \multirow{2}{*}{ - 22 Proper use of personnel } & 2 & 145 & 1 & 115 & 8 & 108 & 3 & 58 & $1.98^{\mathrm{a}}$ & $6.19^{\circ}$ & $2.09^{\mathrm{a}}$ \\
\hline & & (52.5) & & (61.8) & & (28.6) & & (41.7) & $7.54^{\mathrm{c}}$ & $3.59^{\circ}$ & $2.83^{\mathrm{b}}$ \\
\hline \multirow{2}{*}{18 Quality control } & 3 & 117 & 2 & 98 & 14 & 62 & 10 & 32 & $2.15^{\mathrm{b}}$ & $7.36^{\circ}$ & $3.31^{\circ}$ \\
\hline & & (42.4) & & $(52.7)$ & & $(16.4)$ & & $(23.0)$ & $8.98^{\mathrm{c}}$ & $5.41^{\mathrm{c}}$ & 1.72 \\
\hline \multirow{2}{*}{17 Profit consciousness } & 4 & 110 & 4 & 74 & 16 & 52 & 6 & 41 & .02 & $7.63^{c}$ & $2.08^{a}$ \\
\hline & & $(39.9)$ & & $(39.8)$ & & $(13.8)$ & & $(29.5)$ & $6.96^{\mathrm{c}}$ & 1.92 & $4.12^{\mathrm{c}}$ \\
\hline \multirow{2}{*}{4 Innovativeness } & 5 & 90 & 9 & 38 & 5 & 122 & 13 & 24 & $2.87^{\mathrm{b}}$ & .05 & $3.30^{\mathrm{c}}$ \\
\hline & & $(32.6)$ & & $(20.4)$ & & $(32.4)$ & & $(17.3)$ & $2.97^{\mathrm{b}}$ & .70 & $3.38^{\mathrm{c}}$ \\
\hline \multirow{2}{*}{21 Fare treatment } & 6 & 87 & 6 & 63 & 22 & 35 & 16 & 20 & .54 & $7.19^{\circ}$ & $3.76^{\mathrm{c}}$ \\
\hline & & $(31.5)$ & & $(33.9)$ & & $(9.3)$ & & $(14.4)$ & $7.25^{\mathrm{c}}$ & $3.99^{\circ}$ & 1.67 \\
\hline \multirow{2}{*}{6 System development } & 7 & 79 & 5 & 67 & 15 & 53 & 15 & 20 & 1.68 & $4.56^{\mathrm{c}}$ & $3.20^{\mathrm{b}}$ \\
\hline & & (28.6) & & $(36.0)$ & & $(14.1)$ & & $(14.4)$ & $5.97^{\mathrm{c}}$ & $4.45^{\mathrm{c}}$ & .06 \\
\hline \multirow{2}{*}{ - 15 Technical expertise } & 8 & 74 & 7 & 59 & 6 & 117 & 2 & 66 & 1.14 & 1.17 & $4.21^{\mathrm{c}}$ \\
\hline & & $(26.8)$ & & $(31.7)$ & & $(31.0)$ & & $(47.5)$ & .17 & $2.90^{\mathrm{b}}$ & $3.48^{\mathrm{c}}$ \\
\hline \multirow{2}{*}{11 Motivating skill } & 9 & 66 & 8 & 40 & 7 & 115 & 18 & 15 & .60 & 1.86 & $3.18^{\mathrm{b}}$ \\
\hline & & $(23.9)$ & & $(21.5)$ & & $(30.5)$ & & $(10.8)$ & $2.25^{\mathrm{a}}$ & $2.55^{\mathrm{a}}$ & $4.57^{\mathrm{c}}$ \\
\hline \multirow{2}{*}{3 Decision making skill } & 10 & 63 & 10 & 36 & 4 & 134 & 14 & 20 & 1.10 & $3.25^{\mathrm{b}}$ & $2.24^{\mathrm{a}}$ \\
\hline & & $(23.7)$ & & $(19.4)$ & & $(35.5)$ & & $(14.4)$ & $3.91^{\mathrm{c}}$ & 1.18 & $4.65^{\circ}$ \\
\hline \multirow{2}{*}{2 Problem identification } & 12 & 53 & 15 & 28 & 2 & 157 & 9 & 32 & 1.14 & $6.05^{\circ}$ & .91 \\
\hline & & $(19.2)$ & & $(15.1)$ & & $(41.6)$ & & $(23.0)$ & $6.30^{\circ}$ & 1.82 & $3.89^{\circ}$ \\
\hline \multirow{2}{*}{5 Planned action } & 15 & 34 & 11 & 35 & 3 & 140 & 7 & 38 & 1.92 & $7.08^{c}$ & $3.80^{\circ}$ \\
\hline & & $(12.3)$ & & $(18.8)$ & & $(37.1)$ & & (27.3) & $4.41^{\mathrm{c}}$ & 1.82 & $2.08^{\mathrm{a}}$ \\
\hline \multirow{2}{*}{12 Creativity development } & 14 & 37 & 16 & 27 & 9 & 89 & 12 & 25 & .34 & $3.26^{\mathrm{b}}$ & 1.24 \\
\hline & & $(13.4)$ & & $(14.5)$ & & $(23.6)$ & & $(18.6)$ & $2.51^{\mathrm{a}}$ & .85 & 1.36 \\
\hline \multirow{2}{*}{10 Team work } & 20 & 21 & 19 & 15 & 10 & 86 & 1 & 78 & .20 & $5.18^{\mathrm{c}}$ & $10.94^{c}$ \\
\hline & & $(7.6)$ & & $(8.1)$ & & $(22.8)$ & & $(56.1)$ & $4.28^{\mathrm{e}}$ & $9.47^{\circ}$ & $7.21^{\circ}$ \\
\hline \multirow{2}{*}{19 Sensitively to customer needs } & 13 & 51 & 12 & 35 & 11 & 82 & 4 & 49 & .05 & 1.57 & $4.23^{\mathrm{c}}$ \\
\hline & & (26.5) & & (16.7) & & (21.5) & & (35.3) & 1.32 & $3.79^{\mathrm{c}}$ & $3.20^{\mathrm{b}}$ \\
\hline \multirow{2}{*}{7 Delegation } & 19 & 23 & 20 & 14 & 19 & 45 & 8 & 37 & .27 & 1.82 & $5.25^{\circ}$ \\
\hline & & $(7.4)$ & & $(6.7)$ & & (11.8) & & (26.6) & 1.86 & $4.88^{\mathrm{c}}$ & $4.08^{\mathrm{c}}$ \\
\hline
\end{tabular}

Note: ${ }^{\mathrm{a}} \mathrm{p}<.05,{ }^{\mathrm{b}} \mathrm{p}<.01,{ }^{\mathrm{c}} \mathrm{p}<.001$.

- indicates items are common within the first 10 most frequently cited managerial skills among Chinese SOCs and JVCs, Japanese corporations, and Taiwanese corporations. 
SOCs and JVCs for a pilot study.

On the other hand, the first 10 important skills for Japanese managers look quit different. For example, the second, third and fourth frequently cited skills by SOC managers, namely skills of proper use of personnel, quality control and profit consciousness respectively, turned out to be eighth, fourteenth and sixteenth important respectively for JC managers. On the contrary, the second, third and fourth frequently cited skills by JC managers, i.e., skills of problem identification, planned action and decision making, are found to be only at the twelfth, sixteenth and tenth important respectively for SOC managers. Very interestingly, however, a strategic thinking skill maintained at consistently high positions across three groups; It was found most frequently chosen by managers in SOCs and JCs, and third most by those in JVCs, as a critical skill for improving their present level job performance. In summary, rank order correlation coefficients between JC, and SOC and JVC manager groups turned out to be low and non-significant: -.05 and - .35 respectively (see Table 2).

Table 1 also shows that a list of critical skills for Taiwanese managers is also different from that of Japanese and Chinese colleagues. For example, a teamwork skill that the Taiwanese managers reported to be most critical for improving their managerial performance turned out to be the $20^{\text {th }}, 19^{\text {th }}$ and $10^{\text {th }}$ important for SOC, JVC and JC managers respectively. In the same manner, the second critical skill for Taiwanese managers, the technical expertise, was found to be the $8^{\text {th }}, 7^{\text {th }}$ and $6^{\text {th }}$ important for SOC, JVC and JC managers respectively. On the other hand, the third critical skill for Taiwanese managers, proper use of personnel, coincides with the choices by SOC and JVC managers who placed it as the $2^{\text {nd }}$ and $1^{\text {st }}$ important skill respectively. But, again Taiwanese managers were found different from Japanese managers who chose this skill to be only $8^{\text {th }}$ important. The $4^{\text {th }}$ important skill for Taiwanese managers, namely sensitivity to customer needs, showed the same pattern of difference as stated above: $13^{\text {th }}, 12^{\text {th }}$ and $11^{\text {th }}$ for SOC, JVC and JC mana-
Table 2 Spearman's Rank Order Correlation Coefficients Computed Based on the Ten Critical Managerial Skills Ordered in Terms of Average Choice Frequency Made by Managers in Chinese State-owned (SOCs) and Joint Venture Corporations (JVCs), and in Taiwanese (TCs) and Japanese Corporations (JCs)

\begin{tabular}{llllll}
\hline \hline & 1 & 2 & 3 & 4 \\
\hline 1. Chinese state-owned Corporations & - & & & \\
2. Chinese joint venture Corporations & $.83^{*}$ & - & & \\
3. Taiwanese Corporations & .53 & .48 & - & \\
4. Japanese Corporations & -.05 & -.35 & .28 & - \\
\hline
\end{tabular}

Note: * $\mathrm{p}<.05$

gers respectively. But, the $5^{\text {th }}$ and $6^{\text {th }}$ important skills for Taiwanese managers, namely strategic thinking and profit consciousness skills, coincide roughly with choice patterns of Chinese managers in SOCs and JVCs, though again deviated from Japanese managers who gave the $1^{\text {st }}$ and $16^{\text {th }} \mathrm{im}$ portance to these skills respectively. As a result, as Table 2 illustrates the Spearman's rank order correlation coefficients computed between Taiwanese and the others (SOC, JVC and JC managers) involving the first 10 skills listed in Table 1 were found to be $r_{s}=.53, .48$ and .28 respectively.

The result shown in Table 2 suggests that Taiwanese managers are different from both Japanese and Chinese managers, but relatively close to Chinese managers in their choices of critical managerial skills for improving their job performance. However, Japanese managers were found very different; Rank order correlation coefficients turned out very low or even negative with other groups of managers in Table 2.

\section{Skill Practices and Importance of Critical Skills:} A Congruence

A series of analyses were attempted for further exploring implications on the pattern of managerial skill practices as illustrated in Figure 1, given the additional information on critical managerial skills as shown in Table 1. The purpose of these analyses was whether the frequency of practices and importance of the critical skills have a congruence in such a way that the more critical the skills, the more frequently they are practiced. To examine this congruence hypothesis and differences among manager groups, an evaluation of 
Table 3 The frequency (percentage) by which the first three items in each skill factor were chosen as one of the five most important skills by managers in SOCs, JVCs, JCs and TCs

\begin{tabular}{|c|c|c|c|c|c|c|c|c|}
\hline \multirow[t]{2}{*}{ Skills } & \multicolumn{2}{|c|}{$\begin{array}{c}\text { SOC } \\
(n=276)\end{array}$} & \multicolumn{2}{|c|}{$\begin{array}{c}\text { JVC } \\
(n=186)\end{array}$} & \multicolumn{2}{|c|}{$\begin{array}{c}\text { JC } \\
(\mathrm{n}=377)\end{array}$} & \multicolumn{2}{|c|}{$\begin{array}{c}\mathrm{TC} \\
(\mathrm{n}=139)\end{array}$} \\
\hline & Freq. & (\%) & Freq. & (\%) & Freq. & $(\%)$ & Freq. & $(\%)$ \\
\hline Technical skills & 61 & $(22.1)$ & 48 & $(25.8)$ & 72 & $(19.1)$ & 33 & $(23.7)$ \\
\hline 16. Managing by quantitative data & 30 & $(10.9)$ & 19 & $(10.2)$ & 46 & $(12.2)$ & 14 & $(10.1)$ \\
\hline 6. System development & 79 & $(28.6)$ & 67 & $(36.0)$ & 53 & $(14.1)$ & 20 & $(14.4)$ \\
\hline 15. Technical expertise & 74 & $(26.8)$ & 57 & $(30.6)$ & 117 & $(31.0)$ & 66 & $(47.5)$ \\
\hline Proper use of personnel skills & 94 & $(34.1)$ & 71 & $(38.2)$ & 75 & $(19.9)$ & 42 & $(30.2)$ \\
\hline 22. Proper use of personnel & 145 & $(52.5)$ & 115 & $(61.8)$ & 108 & $(28.6)$ & 58 & $(41.7)$ \\
\hline 21. Fare treatment & 87 & $(31.5)$ & 63 & (33.9) & 35 & $(9.3)$ & 20 & (14.4) \\
\hline 19. Sensitively to customer needs & 51 & $(18.5)$ & 35 & $(18.8)$ & 82 & $(21.8)$ & 49 & $(35.3)$ \\
\hline Organizational goal attainment skills & $s \quad 24$ & $(8.7)$ & 18 & $(9.7)$ & 73 & $(19.4)$ & 36 & $(25.9)$ \\
\hline 9. Presenting missions & 14 & $(1.4)$ & 10 & $(5.4)$ & 65 & $(17.2)$ & 11 & $(7.9)$ \\
\hline 8. Providing structure & 37 & $(13.4)$ & 30 & $(16.1)$ & 69 & $(18.3)$ & 19 & $(13.7)$ \\
\hline 10. Teamwork & 21 & $(7.6)$ & 15 & $(8.1)$ & 86 & $(22.8)$ & 78 & $(56.1)$ \\
\hline Organizational development skills & 89 & $(32.2)$ & 48 & $(25.8)$ & 155 & $(41.1)$ & 31 & $(22.3)$ \\
\hline 2. Problem identification & 53 & $(19.2)$ & 28 & (15.1) & 157 & $(41.6)$ & 32 & $(23.0)$ \\
\hline 3. Decision making skill & 63 & $(22.5)$ & 36 & (19.4) & 134 & $(35.5)$ & 20 & $(14.4)$ \\
\hline 1. Strategic thinking & 150 & $(54.3)$ & 80 & $(43.0)$ & 175 & $(46.4)$ & 42 & $(30.2)$ \\
\hline
\end{tabular}

Note : Frequency (percentage) for the factor scale indicates an average of frequencies of the three skill items. SOC: Chinese State-Owned Corporation JVC: Chinese Joint Venture Corporation JC: Japanese Corporation

the critical importance of each skill factor was conducted based on the skill items that constitute each factor shown in Appendix 2. More precisely, the first three most highly loaded skill items were selected in each factor, then the frequency (percentage) by which each skill was chosen as one of the five critical skills was counted, and an average frequency was computed across these three items. Therefore, this average frequency can be interpreted as a measure of criticality attached by managers to each skill factor as needed for improving their job performance.

Table 3 displays the result of the above computations. For example, in Table 3 the three skill items representing the Technical Skill factor, namely skills of management by quantitative data, system development and technical expertise, were found being selected by the 30 (10.9\%), 79 (28.6\%) and 74 (26.8\%) Chinese SOC managers respectively out of 276 managers, as constituting the critical skills needed for them to improve the present level of job performance. Then, an average frequency (22.1\%) was computed as a measure of the importance of

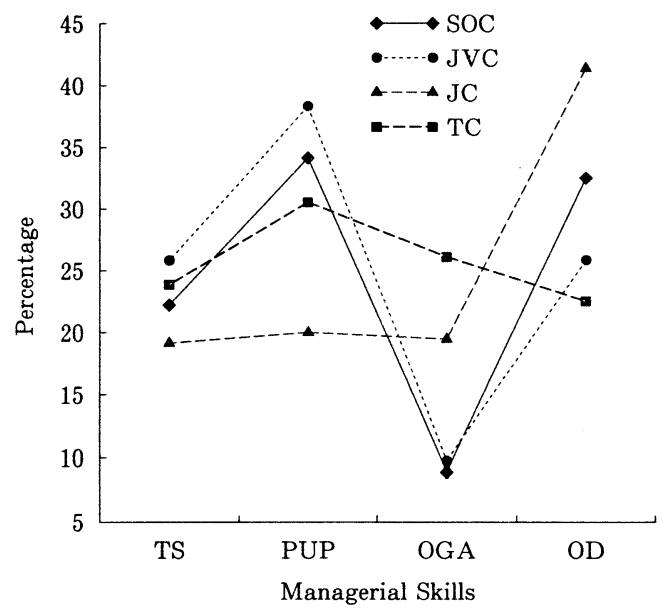

Figure 2 The Percentage of Four Managerial Skills Chosen as Critical by Skills Managers in Four Different Management Organizations

TS factor for managers in SOCs. The same procedures were repeated for JVCs, JCs and TCs. Figure 2 graphically displays the level of critical importance of all skill factors computed in the same manner as a TS factor.

Figure 2 clearly indicates that Japanese mana- 
gers choose Organizational Development (OD) skills, while Chinese managers in SOCs and JVCs do Proper Use of Personnel (PUP) skills, and managers in TCs do Organizational Goal Attainment (OGA) skills most frequently as critically important ones for improving their present job performance. These findings presented in Figure 2 give support to Hypothesis 2. Namely, the PUP skills featured by skills of proper use of personnel and fair treatment are found most critical for Chinese managers as Hypothesis 2 indicates. Likewise, for Japanese managers the OD skills which include strategic thinking and decision making skills are reported most critical in Figure 2, while for Taiwanese managers the OGA skills consisting of skills of teamwork, providing structure and presenting missions, are found most critical. These results as a whole render support to Hypothesis 2.

For the next step, it is necessary to examine the relationship between the frequency of the skill practice and the importance of that critical skill for improving managerial job performance. After comparing the results presented in Figure 1 (showing the frequency of skill use) and Figure 2 (showing the importance of critical skills), it was found that Chinese and Taiwanese managers are practicing people-oriented skills more frequently, and at the same time recognize these skills to be critical for improving performance on their jobs. In the same manner, Japanese managers are practicing strategy-oriented skills more frequently and also consider these skills are critical. This finding suggests that in general the frequency of practicing a certain skill tends to have a high correlation with the criticality of that skill. This is particularly true for Japanese managers who demonstrated a consistent pattern between the frequency of skill use (in Figure 1) and the importance of critical skills (Figure 2) across all four skills.

One contradictory finding to this correlation relations is the fact that Chinese managers in SOCs and JVCs equally report OGA skills to be far less critical for the improvement of their managerial performance in Figure 2, although they are reporting rather frequent practices of OGA skills in Figure 1. Another inconsistency is found in OD skills where the critical importance is highly recognized, while the frequency of its practices is the lowest.

Taiwanese managers report another contradictory results. In Figure 1, Taiwanese managers report the highest frequency of practicing TS, PUP and OGA skills in all four groups, however, the criticality of these skills are not necessarily comparably high in Figure 2. Particularly, this contradictory result is quite evident for Taiwanese managers in OD skills that are reported to be practiced as frequently as Japanese colleagues, but the critical importance of the OD for Taiwanese managers are the lowest in all four groups; The difference is outstanding against Japanese managers as shown in Figure 2.

In summary, Hypothesis 2 can be maintained in principle based on the evidence provided by Figure 2. However, inconsistencies between the frequency of practices and the critical importance of skills emerged. Taiwanese managers demonstrated the most serious inconsistency, while Japanese managers showed rather consistent results between the skill practice and skill criticality. Chinese managers are found consistent in PUP skills, but inconsistent in OGA and OD skills.

\section{Critical Skill Practices in the Business Perform- ance Process: Comparisons among Japanese, Chinese and Taiwanese Managers}

Table 4 further summarizes critical skills by listing the first five most frequently chosen skills from Table 1 for Japanese, Chinese and Taiwanese managers. Since a rank order correlation is very high between Chinese SOC and JVC managers, they are grouped into a single Chinese manager group in Table 4. It is evident from Table 4 that the first five most frequently chosen skills as critical for improving managerial performance are different among three groups. In other words, Japanese managers tend to place strategic thinking and problem identification skills as most critical for their job performance. On the other hand, Chinese managers in both SOCs and JVCs 
Practices of Critical Managerial Skills:

Table 4 Comparisons of Critical Managerial Skills in Order of Frequency of Choices by Japanese, Chinese and Taiwanese Managers

\begin{tabular}{|c|c|c|c|c|c|c|}
\hline \multirow{2}{*}{$\begin{array}{l}\text { Frequency } \\
\text { of Choice }\end{array}$} & \multicolumn{2}{|c|}{ Japanese Managers } & \multicolumn{2}{|c|}{ Chinese Managers } & \multicolumn{2}{|l|}{ Taiwanese Managers } \\
\hline & Stra & & Pron & & & ) \\
\hline & Pro & $(4$ & $m_{5}$ & & $\mathrm{~T}$ & 5) \\
\hline & ned action & $(37$ & $\mathrm{Qu}$ & $(46.5)$ & Proper use & $1(41.7)$ \\
\hline Fourth & Decision making & $(35.5)$ & Profit consciousness & $(39.8)$ & Sensitivity $\mathrm{t}$ & $(35.3)$ \\
\hline Fifth & Innovativeness & $(32.4)$ & Fair treatment & $(32.5)$ & Strategic thinking & $(30.2)$ \\
\hline
\end{tabular}

Note: Numbers in parentheses denote percentages.

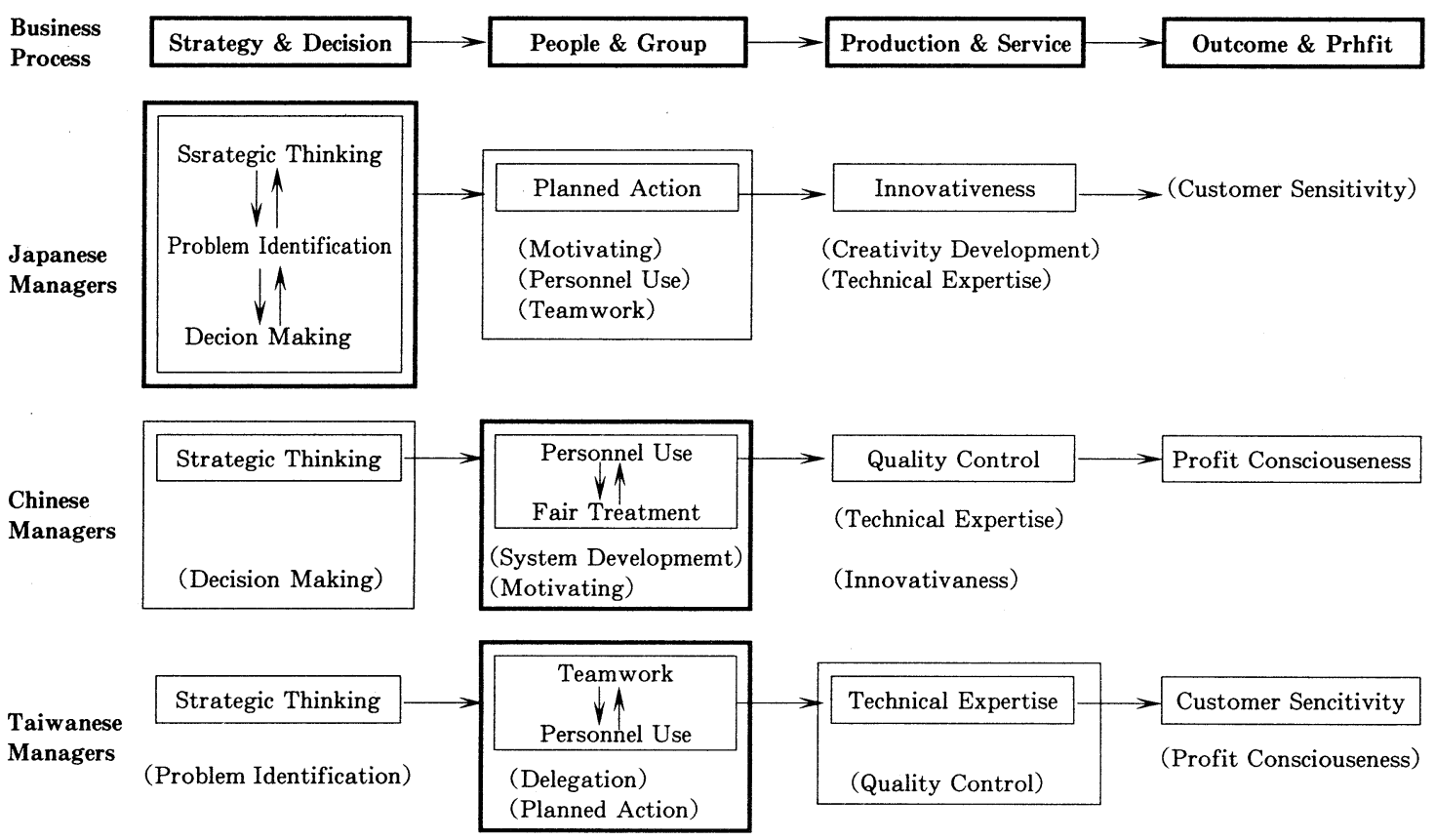

Note: Skills in squares indicate the first five critical skills, while those in parentheses indicate the sixth to the tenth skills shown in Table 1.

Figure 3 Differences in High Performance Strategies among Japanese, Chinese and Taiwanese Managers: Based on the Exercise of Critical Managerial Skills in the Business Process

choose people-oriented skills (proper use of personnel and fair treatment) and skills for production and outcomes (quality control and profit consciousness) as critical skills for increasing their job performance. On the contrary, Taiwanese managers tend to place team-oriented skills (teamwork and proper use of personnel) and expert skills (technical expertise and sensitivity to customer needs) to be most critical for their jobs. Again, these differences among three manager groups, although not necessarily being quite clear and objective, give support to Hypothesis 2 that states Chinese managers choose people-oriented skills as critical for improving their job performance, while Taiwanese managers do partnership and teamwork skills, and Japanese managers do problem solving and strategic decision making skills.

Figure 3 illustrates configurations of critical managerial skills for Japanese, Chinese and Taiwanese managers distributed along the business process that gets started from the initial 
phase of formulating strategies and making decisions, energized through the phases of mobilizing people and groups for generating production and services, then terminated in the final phase of outcome and profit making. In Figure 3, critical skills for Japanese managers are found occurring around the initial, strategy and decision making phase in the performance process. In other words, for Japanese managers the initial phase in the business performance process involving the problem finding and strategy formulation skills, tends to stand out as critical for ensuring the high performance process to take off. Therefore for Japanese managers, skills of moving the initial stage forward, namely the strategic thinking, problem identification and decision making skills, constitute the critical skill mix for improving their job performance. Then for the next stage, the skill of planned action, accompanied by the motivating, proper use of personnel and teamwork skills, are considered critical for mobilizing people and a group along the business process towards generating outcomes and profit.

However, for Chinese managers the critical phase for achieving high performance is in the second, people and group mobilization phase in which skills of proper use of personnel and fair treatment play a critical role. These peopleoriented skills are selected as critical by Chinese managers associated with the system development and motivating skills. According to Figure 3, these people-oriented skills are believed to be critical, only after strategies and decisions are made in the initial phase which looks not quit salient in Chinese corporations. Figure 3 also indicates that for Chinese managers peopleoriented skills become critical for enhancing production and services in the next phase where the quality control skill plays an important role followed by skills of innovativeness and technical expertise. Generally speaking, Chinese managers have a tendency to distribute critical skills around the second and the third phase in the business performance process, while Japanese colleagues do around the initial phase.

Likewise, Taiwanese managers are found to distribute mostly critical skills around the second, people and a group mobilization phase in the business process. For Taiwanese managers, however, critical skills needed for improving job performance are team-oriented ones, while for Chinese managers people-oriented skills, namely proper use of personnel and fair treatment skills, are found more critical in this phase. It seems that an emphasis is placed on the association of teamwork and planned actions skills for Taiwanese managers, while for Chinese managers the association of fair treatment and motivating skills is critical. In other words, Taiwanese managers are team-oriented, while Chinese managers are people-oriented in their efforts to mobilize internal human resources for achieving production and profit outcomes. This contrast in the emphasis of human resource utilization between Chinese and Taiwanese managers can be attributable to the difference in the respective corporate culture: an emphasis on harmony and equality for motivating people in Chinese culture vs. partnership among team members for the planned action in Taiwanese culture. Both China and Taiwan can be classified into the collectivism and Confucian society (Hofstede, 1980; Hofstede and Bond, 1988), but skills that managers practice in their corporations for mobilizing internal human resources were found quite different each other.

In Figure 3, skills considered critical at the third phase in the business process, namely the production and service development phase, were found also different among three groups of managers. Japanese managers emphasize an innovative skill to be most critical followed by skills of creativity development. On the other hand, Chinese and Taiwanese managers choose a skill of quality control and technical expertise to be critical. However, a difference exists between Chinese and Taiwanese managers such that the former stresses quality control and the latter technical expertise as the most critical one. In the final, outcome and profit generating phase, either profit consciousness skill or a skill of customer sensitivity is reported to be critical for all three groups of managers. However, among Japanese managers 
both skills are not considered so critical: Customer sensitivity is ranked only at the eleventh importance, and profit consciousness at the sixteenth.

\section{Conclusions and Discussions}

In summary, configurations of critical managerial skills distributed along the business performance process can be characterized for Japanese, Chinese and Taiwanese managers as shown in Figure 4. Japanese managers place a primary emphasis on the strategy and decision making phase in the business performance process in Figure 4. Then, they exercise the skill of planned action for facilitating the people and group utilization process. This process corresponds to the mechanism of human resource mobilization and management in Japanese corporations. In the production and service management phase, a skill of innovation becomes highlighted for Japanese managers as critical for improving their job performance. Finally, sensitivity to customer needs is recognized as a critical skill for generating the ultimate outcome and profit, but for Japanese managers salience of this skill seems weak relative to other critical skills. In summary, Japanese managers are following the pattern of strategy-driven managerial skill practices. In other words, they strongly emphasize and most frequently utilize skills of problem identification, strategic thinking and decision making. They believe this is the way to the performance improvement in Japanese corporations.

Next, Chinese managers were found placing the strongest emphasis on the skill of proper use of personnel. Moreover, this is the most frequently practiced skill for Chinese managers. Although, the strategic thinking skill is considered highly critical, it is not practiced so frequently among Chinese managers. In other words, Chinese managers exhibit inconsistency concerning the strategic thinking skill between the judgment of its criticality and the frequency of actually practicing it.

For Chinese managers, skills of treating people fairly and motivating them to work are considered most critical. At the same time, they consider skills of quality control and profit consciousness critically important to facilitate the process of production and service generation, and of profit making. This pattern of critical skill practices among Chinese managers is characterized as people-oriented managerial skill practices, since using people properly is considered critical for generating outcomes.

Finally it was found that Taiwanese managers, like their Chinese colleagues, consider the phase of people and group management is most salient in the business performance process. For Taiwanese managers, the teamwork skill is most critical in this phase, followed by skills of proper use of personnel and fair treatment. Thus, maintaining teamwork based on skills of fair treatment and proper personnel use becomes a central concern for Taiwanese managers. Also, technical expertise seems equally critical for Taiwanese managers at the phase of production and service, followed by customer sensitivity at the final outcome phase. The above sequence of critical skills suggests that for Taiwanese managers the business performance process is facilitated primarily by the teamwork-oriented managerial skill practices.

It seems that Taiwanese managers are different from Chinese managers; They emphasize skills of

\begin{tabular}{lll}
\hline & Strategr \& Decision $\rightarrow$ People \& Group & $\rightarrow$ Production \& Service $\rightarrow$ Outcome \& Profit \\
\hline Japanese Managers: & Strategic Thinking $\rightarrow$ Planned Action & $\rightarrow$ Innovativeness \\
Chinese Managers: & Strategic Thinking $\rightarrow$ Proper Use of Personnel $\rightarrow$ Quality Control $\rightarrow$ Customer \\
Taiwanese Managers: & Strategic Thinking $\rightarrow$ Teamwork & $\rightarrow$ Technical Expertise $\rightarrow$ Profit
\end{tabular}

Note: Skills in bold characters denote the most salient critical for three groups of managers.

Figure 4 Different Configurations of Critical Skills along the Business Performance Process for Japanese, Chinese and Taiwanese Managers 
teamwork and technical expertise, while their Chinese colleagues tend to associate fair treatment with quality control skills as a most critical set of skills for improving their job performance. This difference looks subtle, but profound. Taiwanese managers, especially young professionally oriented managers, are striving to nurture skills of partnership in the teamwork context. In addition, they emphasize that developing technical expertise in their line of professions must be the way to become an effective partner in the team.

\section{References}

Adler, N. C. (1991). International dimension of organizational behavior. Boston: Kent Publishing.

Boulgardes, J. D. and Oh, D. M. (1985). A comparison of Japanese, Korean and American managerial decision styles. Leadership and Organization Development Journal. 6, 9-11

Bray, D. W., Campbell, R. J. And Grant, D. I. (1974). Formative years in business: A longterm $A T \& T$ study of managerial lives. New York: Wiley

Chen, Z. and Wakabayashi, M. (1997a). Managerial skills in Chinese state-owned corporations. Japanese Journal of Administrative Behavior. 11, 35-48.

Chen, Z. and Wakabayashi, M. (1997b). Managerial skill requirements in China: A comparative study between Chinese managers in Japanese JVCs and Chinese state-owned corporations. Japanese Journal of Administrative Behavior. 11, 59-80.

England, G. W. (1978). Managers and their value systems: A five-country comparative study. Columbia Journal of World Business. 13 (No.2).

Finckle, R. B. (1978). Managerial assessment center. In M. D. Dunnette (Ed.) Handbook of industrial and organizational psychology. 861-888, Chicago: Rand McNally College Publishing.

Fisher, G. (1980). International negotiation: A cross-cultural perspective. Chicago: Intercultural Press

Graen G. B. and Cashman, J. (1975). A rolemaking model of leadership in formal organizations: A developmental approach. In J. G. Hunt and L. L. Larson (Eds.), Leadership Frontiers. 143-166, Kent, OH: Kent University Press.

Hofstede, G. (1980). Cultures consequences: International differences in work- related values. Beverly Hills, CA: Sage Publishing.

Hofstede, G and Bond, M. H. (1988). The Confucius and economic growth: New trends in cultures consequences. Organizational Dynamics. 16, 4-21.

Hwang K. K. (1995). The struggle between Confucianism and Legalism in Chinese Society and Productivity: The Taiwanese experience. In Hwang, K. K. (Ed.) Easternization: Sociocultural impact on productivity. Tokyo: Asian Productivity Organization.

Ishida. H. (1995). Post-takeover management of foreign firms by Japanese corporations: Problems of Japanese style human resource management. Keio Management Forum. 11, 1-18 (in Japanese).

Kagono, T., Nonaka, I., Sakakibara, K, and Okumura, H. (1975). Comparative study of Japanese and American management: A theory of strategic environmental adaptation. Tokyo: Nippon Keizai Shinbun (in Japanese).

Laurent, A. (1983). The cultural diversity of Western conceptions of management. International studies of management and organization. Vol. VIII, 75-96.

Minztberg, H. (1973). The nature of managerial work. New York: Harper.

Redding, S. G. (1990). The spirit of Chinese capitalism. New York, de Gruyter.

Redding, S. G. and Wong, Y. Y. (1986). The psychology of Chinese organizational behaviour. In Bond, M. H. (Ed.), The psychology of Chinese people. Hong Kong: Oxford University Press.

Sawaki, S. (1993). International human resource development in Japanese firms. In $\mathrm{K}$. 
Haraoka and M. Wakabayashi (Eds.), Organizational communication. 180-198. Tokyo: Fukumura Publishing (in Japanese).

Szilagyi, Jr., A. D. and Wallace, Jr., M. C. (1987). Organizational behavior and performance. Glenview, IL: Scott, Foresman and Company. Wang, Z. M. (1990). Human resource management in China: Recent trends. In R. Piepre (Ed.), Human resource management: An international comparison. Berlin: Walter de Gruyter.

Wakabayashi, Mitsuru (1980). Managerial career progress in a Japanese organization. Ann Arbor. MI: UMI Research Press.

Wakabayashi, Mitsuru and Chen, Ziguang (1999). Managerial skills for Asian managers: Comparisons based on Managers in Japanese, Chinese and Filipino corporations. Forum of International Development Studies. 12, Nagoya University: Nagoya, Japan.

Wakabayashi, M. \& Graen, G. B. (1984). The Jàpanese career progress study: A 7-year follow-up. Journal of Applied Psychology. 69, 603-614.

Wakabayashi, M. \& Graen, G. B. (1988). Human resource development of Japanese managers: Leadership and career investment. In $\mathrm{K}$. Rowland \& G. Harris (Eds.), International human resources management: International Review. 135-138. Greemwich, CT: JAI Press.

Wakabayashi, M. and Graen, G. B. (1991). Crosscultural human resource development: Japanese manufacturing firms in central Japan and central US States. In M. Trever (Ed.), International business and the management of change. Brookfield, VT: Avebury.

Wakabayashi, M., Graen, G. B. \& Uhl-Bien, M. (1990). Generalizability of the hidden investment hypothesis among line managers in five leading Japanese corporations. Human Relations. 43, 1099-1116.

(平成11年 4 月 20 日受稿, 平成11年 5 月 10 日受理) 
Appendix 1

\section{Descriptions of the 22 managerial skills}

1. Strategic thinking: considers market situations, competitors, future goals and long-term company prosperity, when making decisions.

2. Problem identification: anticipates future problems and investigates causes and possible consequences.

3. Decision making skill: makes timely decisions under uncertainty and risk-involved situations.

4. Innovativeness: goes beyond the status quo and implement new ideas.

5. Planned action: develops short- and long-term plans and executes one's jobs by following the plan.

6. System development: introduces necessary rules and procedures to get jobs done effectively.

7. Delegation: assigns responsibilities, delegates authorities and provides resources to let others execute task requirements.

8. Providing structure: provides clear goals and priorities, and clarifies roles and responsibilities for each person.

9. Presenting missions: develops missions and common visions for the work group, and encourages others to carry out the missions.

10. Teamwork: solves problems and enhances communication within the team to foster collaboration among team members.

11. Motivating skill: encourages others to challenge difficult tasks, creates enthusiasm in others, and supports achieving behaviors.

12. Creativity development: stimulates subordinates to initiate improvements and supports innovative thinking.

13. Consensus building skill: encourages others to share common ideas by promoting mutual understanding and conflict resolution.

14. Integrity: shows sound thoughts and ethics, and behaves in a consistent way among principles, beliefs and values.

15. Technical expertise: demonstrates up to-date-knowledge in industry and establishes oneself as an expert in the profession.

16. Managing by quantitative data: establishes numerical goals, sets budget, monitors the process by using quantitative information.

17. Profit consciousness: emphasizes the profit targets, and stresses cost saving and profit making behaviors.

18. Quality control: establishes standards for high quality products and services, and exercises strong control for realizing them.

19. Sensitivity to customer needs: tries hard to meet customer needs and looks for better ways to increase customer satisfaction.

20. Group membership skill: puts group goals ahead of personal ones and contributes to achieving group goals collaborating with others.

21. Fair treatment: treats one's subordinates in a fair manner, and provides equal support and encouragement to all group members.

22. Proper use of personnel: chooses the right person for the right job based on the accurate assessment of each subordinate's ability. 
Practices of Critical Managerial Skills:

Appendix 2 The result of a factor analysis on the opportunities of using managerial skills of Chinese and Japanese managers

\begin{tabular}{|c|c|c|c|c|c|}
\hline Item & F1 & $\overline{\mathrm{F} 2}$ & $\overline{\mathrm{F} 3}$ & F4 & $\mathrm{h}^{2}$ \\
\hline F1: Organizational goal attainment & $\alpha=.85$ & & & & \\
\hline 9. Presenting missions & .69 & .19 & .19 & .08 & .55 \\
\hline 8. Providing structure & .64 & .23 & .12 & .22 & .53 \\
\hline 10. Teamwork & .63 & .17 & .12 & .09 & .45 \\
\hline 11. Motivating skill & .60 & .33 & .18 & .15 & .52 \\
\hline 7. Delegation & .52 & .24 & .25 & .17 & .42 \\
\hline 12. Creativity development & .47 & .25 & .27 & .12 & .37 \\
\hline 13. Consensus building skill & .43 & .21 & .36 & .09 & .37 \\
\hline F2. Proper use of personnel & & $\alpha=.81$ & & & \\
\hline 22. Proper use of personnel & .37 & .62 & .14 & -.02 & .54 \\
\hline 21. Fair treatment & .39 & .60 & .13 & .05 & .53 \\
\hline 19. Sensitively to customer needs & .17 & .56 & .16 & .15 & .39 \\
\hline 17. Profit consciousness & .14 & .54 & .15 & .32 & .44 \\
\hline 20. Group membership skill & .36 & .46 & .27 & .12 & .43 \\
\hline 14. Integrity & .22 & .45 & .19 & .22 & .34 \\
\hline F3. Organizational development & & & $\alpha=.71$ & & \\
\hline 2. Problem identification & .26 & .10 & .65 & .17 & .53 \\
\hline 3. Decision making skill & .17 & .13 & .59 & .04 & .40 \\
\hline 1. Strategic thinking & .08 & .19 & .53 & .16 & .35 \\
\hline 4. Innovativeness & .19 & .06 & .43 & .26 & .29 \\
\hline F4. Technical skills & & & & $\alpha=.63$ & \\
\hline 16. Managing by quantitative data & .16 & .22 & .24 & .46 & .34 \\
\hline 6. System development & .38 & .18 & .13 & .44 & .39 \\
\hline 15. Technical expertise & .05 & .21 & .14 & .41 & .23 \\
\hline \multicolumn{6}{|l|}{ Residual items: } \\
\hline 5. Planned actions & .36 & .03 & .33 & .34 & \\
\hline 18. Quality control & .14 & .60 & .01 & .40 & \\
\hline Variance explained & 3.15 & 2.35 & 1.89 & 1.02 & 8.41 \\
\hline Percentage of variance explained & 15.75 & 11.75 & 9.45 & 5.10 & 42.05 \\
\hline
\end{tabular}

